Check for updates

London, UK

Cite this as: $B M J 2021 ; 375: n 2370$ http://dx.doi.org/10.1136/bm..n2370 Published: 18 October 2021

\section{Why I ... have an allotment}

\section{Harriet Feldman, an academic clinician at the department of psychiatry at Oxford University, talks to Helen Jones about how her allotment has boosted her wellbeing and changed her diet}

\section{Helen Jones}

"When we moved into our house in 2018, it had a real jungle of a garden, so my partner and I stripped it back, browsed the seed catalogues, and started growing some vegetables. Then an allotment became available and it's now become a bit of an obsession," says Feldman, who spends between five and 10 hours a week working on her plot during the summer months.

She is growing kohlrabi, mustard greens, and winter brassicas, alongside other vegetables, but her favourite thing to grow is tomatoes. "There's nothing like a fresh tomato off the vine, warm from the sun," she says. "I'd never really cooked with fresh tomatoes before, but they're lovely. We canned quite a lot last summer and are still living off them."

This year she is trying new varieties of chillies and aubergines in a polytunnel, as well as beans, courgettes, cucumbers, raspberries, spinach, and strawberries.

She admits that she knew very little about growing vegetables before she started. "I read a lot of books and spent a lot of time on the internet-there are some YouTube gardeners who are really useful to watch," she says.

“The reason we've done so well is that we haven't given up when things have died, or not grown, or been covered in slugs. Our celery is either dead or stringy and we put in a lot of green beans that have been eaten by muntjac deer. It's not all been plain sailing and we have messed up, but gardening is very forgiving and you can kill things as you learn-unlike in medicine."

As well as providing fresh fruit and veg for her family, Feldman says that her allotment came into its own during lockdown. "It was part of our daily exercise and has become such a step change in my wellbeing," she says. "It's so healthy to spend time outdoors and it's really vigorous. I also sleep better."

She adds, "They say gardening is as energetic as going to the gym, but it's very flowing, natural movement. I've never done formal mindfulness, but if I'm doing a repetitive task such as hoeing the weeds, I become absorbed in the physicality of it. It's about working with my hands-it's satisfying and very different to a lot of the work we do as doctors, which is an intellectual, and often a communication, challenge."

Feldman adds that despite social distancing, her allotment has provided a sense of community during covid-19. "It's like living in a house with no walls. Everyone can see what you're growing and comes over for a chat. The allotment committee drew new energy from lockdown and so we've decided to do communal water collection and grow a communal orchard. Last year, we built a communal chicken coop-there are 16 of us taking part and once a week I go with my son to let the chickens out-we share the work and the eggs."

Feldman says that growing her own produce has also changed the way in which she and her family eat. "Every meal starts with asking, 'What veg do we have and how do we use it up?' Veg is not something we add, it's where we begin. We are now mostly vegetarian, especially in the summer."

She says that she's now spreading her enthusiasm for gardening among her colleagues. "We had big plans to set up a communal growing plot for junior doctors-because you rotate, a communal plot is ideal for people who won't be in the same location long term. Covid-19 has meant that we haven't been able to meet in big groups, but a lot of colleagues are growing things like tomatoes on a windowsill. I haven't had a job yet where there hasn't been someone to talk about gardening with."

\section{How to get started}

- You don't have to have an allotment to grow your own. You can start in any space, even a pot on the windowsill

- There is a lot of good advice on how to grow fruit and veg on YouTube

- Start with something simple, such as potatoes or strawberries, which grow easily and will give you a rush of enjoyment

- Accept that some things will fail-it doesn't mean you are a bad gardener 